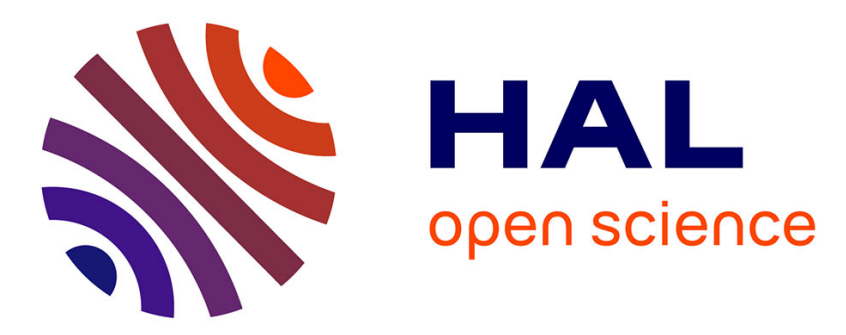

\title{
Effects of Al Addition and Minor Elements on Oxidation Behaviour of FeCr Alloys
}

\author{
J.-M. Herbelin, M. Mantel
}

\section{To cite this version:}

J.-M. Herbelin, M. Mantel. Effects of Al Addition and Minor Elements on Oxidation Behaviour of FeCr Alloys. Journal de Physique IV Proceedings, 1995, 05 (C7), pp.C7-365-C7-374. 10.1051/jp4:1995744 . jpa-00254038

\section{HAL Id: jpa-00254038 https://hal.science/jpa-00254038}

Submitted on 1 Jan 1995

HAL is a multi-disciplinary open access archive for the deposit and dissemination of scientific research documents, whether they are published or not. The documents may come from teaching and research institutions in France or abroad, or from public or private research centers.
L'archive ouverte pluridisciplinaire HAL, est destinée au dépôt et à la diffusion de documents scientifiques de niveau recherche, publiés ou non, émanant des établissements d'enseignement et de recherche français ou étrangers, des laboratoires publics ou privés. 


\title{
Effects of Al Addition and Minor Elements on Oxidation Behaviour of FeCr Alloys
}

J.-M. Herbelin and M. Mantel

Ugine Research Center, Ugine Savoie, 73403 Ugine cedex, France

\begin{abstract}
It is shown that the addition of aluminium is very effective for the high temperature oxidation resistance of $\mathrm{FeCr}$ alloys. $1 \%$ aluminium produces a continuous protective $\mathrm{Al}_{2} \mathrm{O}_{3}$ oxide for $\mathrm{FeCr}$ alloy that contains more than $13 \%$ of chromium. However this aluminium content is not enough for the high temperature resistance of thin foils and a $5 \%$ aluminium content is needed since the substrate plays the role of an aluminium reserve susceptible to oxidation. Impurity elements such as sulphur are detrimental and give rise to scaling of the oxide layer. Active elements such as $\mathrm{Y}, \mathrm{Ce}, \mathrm{La}, \mathrm{Zr}$ are therefore necessary to tie up sulphur and increase the life of the alloys.
\end{abstract}

\section{INTRODUCTION}

For temperatures up to $1000^{\circ} \mathrm{C}$, chromium in alloys leads to the formation of a protective $\mathrm{Cr}_{2} \mathrm{O}_{3}$ layer.

$\mathrm{Fe}-\mathrm{Cr}$ grades without a high level of aggressive elements $\left(\mathrm{Cl}^{-}, \mathrm{F}^{-}\right)$are the best compromise for cheap, heat resistant alloys. At higher temperatures $\left(\mathrm{T} 1000^{\circ} \mathrm{C}\right)$, degradation of oxidation resistance is observed until the formation of $\mathrm{a} \mathrm{CrO}_{3}$ volatile layer (1). For this reason, aluminium should be added cautiously. However high $\mathrm{Cr}$ and $\mathrm{Al}$-content alloys are fairly brittle and make production difficult. These characteristics are rather incompatible with mass production. One of the objectives of the present study is to determine, on the basis of experimental and thermodynamic parameters, the critical aluminium and chromium contents to produce a protective alumina scale. In order to diminish $\mathrm{Al}$ and $\mathrm{Cr}$ contents, addition of different minor elements must be controlled. The effect of impurities on the basis of oxidation behaviour is also given. One of the applications concerns metal carriers for catalytic converters. The metal substrate must have very high oxidation resistance due to the high-temperature service conditions and its thickness $(50 \mu \mathrm{m})$.

\section{EXPERIMENTAL}

\section{1 Laboratory casts :}

The materials used were from $25 \mathrm{~kg}$ ingots cast in argon. The casts were then rolled into sheets of $1.5 \mathrm{~mm}$ and foils of $50-60 \mu \mathrm{m}$ thick. Samples were annealed for a few minutes in an inert atmosphere at $1000^{\circ} \mathrm{C}$.

The chemical compositions of the alloys studied are given below.

\begin{tabular}{|c|c|c|c|c|c|c|c|c|c|c|c|c|c|}
\hline & $\begin{array}{c}\text { (a) } \\
\mathrm{Fe} 17 \mathrm{Cr} \\
0.03 \mathrm{Al}\end{array}$ & $\begin{array}{c}\text { (b) } \\
\mathrm{Fe} 17 \mathrm{Cr} \\
0.5 \mathrm{Al} \\
\end{array}$ & $\begin{array}{c}\text { (c) } \\
\mathrm{Fe} 17 \mathrm{Cr} \\
1 \mathrm{Al} \\
\end{array}$ & \begin{tabular}{|c} 
(d) \\
$\mathrm{Fe} 17 \mathrm{Cr}$ \\
$2 \mathrm{Al}$ \\
\end{tabular} & $\begin{array}{c}\text { (e) } \\
\mathrm{Fe} 6 \mathrm{Cr} \\
2 \mathrm{Al} \\
\end{array}$ & $\begin{array}{c}\text { (f) } \\
\mathrm{Fe} 13 \mathrm{Cr} \\
2 \mathrm{Al} \\
\end{array}$ & \begin{tabular}{|c}
$(\mathrm{g})$ \\
$\mathrm{Fe} 20 \mathrm{Cr}$ \\
$2 \mathrm{Al}$ \\
\end{tabular} & \begin{tabular}{|c} 
(h) \\
$\mathrm{Fe} 18 \mathrm{Cr}$ \\
$2 \mathrm{Al}$ \\
\end{tabular} & \begin{tabular}{|c|} 
(i) \\
$\mathrm{Fe} 18 \mathrm{Cr}$ \\
$2 \mathrm{AlY}$ \\
\end{tabular} & $\begin{array}{c}\text { (j) } \\
\text { Fe17Cr } \\
2 \mathrm{AlY}\end{array}$ & $\begin{array}{c}\text { (k) } \\
\mathrm{Fe} 17 \mathrm{Cr} \\
2 \mathrm{Al} \\
\end{array}$ & $\begin{array}{c}\text { (l) } \\
\mathrm{Fe} 18 \mathrm{Cr} \\
4 \mathrm{Al} \mathrm{Zr} \\
\end{array}$ & \begin{tabular}{|c|}
$(\mathbf{m})$ \\
$\mathrm{Fe} 18 \mathrm{Cr}$ \\
$4 \mathrm{Al} \mathrm{Zr}$ \\
\end{tabular} \\
\hline $\mathrm{C}$ & 0.019 & 0.017 & 0.023 & 0.014 & 0.024 & 0.019 & 0.021 & 0.004 & 0.010 & 0.020 & 0.017 & 0.015 & 0.022 \\
\hline $\mathrm{Si}$ & 0.323 & 0.332 & 0.344 & 0.272 & 0.352 & 0.336 & 0.279 & 0.444 & 0.38 & 0.359 & 0.302 & 0.401 & 0.398 \\
\hline $\mathrm{Mn}$ & 0.426 & 0.411 & 0.423 & 0.416 & 0.436 & 0.421 & 0.395 & 0.403 & 0.419 & 0.418 & 0.445 & 0.361 & 0.404 \\
\hline $\mathrm{Cr}$ & 16.65 & 16.48 & 16.44 & 16.58 & 6.142 & 12.90 & 19.79 & 18.44 & 18.34 & 16.13 & 16.43 & 18.04 & 18.22 \\
\hline$S$ & $41 \mathrm{ppm}$ & $35 \mathrm{ppm}$ & $40 \mathrm{ppm}$ & $35 \mathrm{ppm}$ & $31 \mathrm{ppm}$ & $35 \mathrm{ppm}$ & $38 \mathrm{ppm}$ & $26 \mathrm{ppm}$ & $10 \mathrm{ppm}$ & $10 \mathrm{ppm}$ & $23 \mathrm{ppm}$ & $50 \mathrm{ppm}$ & $20 \mathrm{ppm}$ \\
\hline $\mathrm{Al}$ & 0.027 & 0.5 & 1.04 & 1.9 & 2.09 & 2.04 & 1.93 & 1.97 & 2.0 & 1.89 & 2.10 & 5.20 & 4.70 \\
\hline $\mathrm{Zr}$ & 0.267 & 0.303 & 0.305 & 0.333 & 0.368 & 0.279 & 0.307 & $<0.002$ & $<0.002$ & 0.301 & 0.295 & 0.276 & 0.314 \\
\hline $\mathrm{Nb}$ & 0.465 & 0.482 & 0.462 & 0.483 & 0.487 & 0.467 & 0.469 & $<0.002$ & $<0.003$ & 0.466 & 0.480 & 0.002 & $<0.002$ \\
\hline $\mathrm{O}$ & $54 \mathrm{ppm}$ & $42 \mathrm{ppm}$ & $37 \mathrm{ppm}$ & $23 \mathrm{ppm}$ & $4 \mathrm{ppm}$ & $32 \mathrm{ppm}$ & $32 \mathrm{ppm}$ & $17 \mathrm{ppm}$ & $5 \mathrm{ppm}$ & $10 \mathrm{ppm}$ & $6 \mathrm{ppm}$ & $24 \mathrm{ppm}$ & $16 \mathrm{ppm}$ \\
\hline $\mathrm{N}$ & 0.017 & 0.021 & 0.016 & 0.015 & 0.001 & 0.016 & 0.019 & 0.019 & 0.01 & 0.011 & 0.012 & 0.008 & 0.011 \\
\hline $\mathrm{Y}$ & & & & & & & & & 0.012 & 0.013 & & & \\
\hline
\end{tabular}




\section{2 Oxidation procedure}

The coupons of $1.5 \mathrm{~mm}$ were polished to 1200 paper grade. Before oxidation tests, the samples were cleaned in an ultrasonic alcohol bath. Oxidation tests were carried out in air from $900^{\circ} \mathrm{C}$ to $1100^{\circ} \mathrm{C}$. The weight of the samples was measured before and after the heat treatment in order to determine the weight gain corresponding to the oxidation behaviour. Each point of oxidation kinetics represents the average value of 3 different samples.

\section{RESULTS}

\section{1 Influence of aluminium content}

\section{1. 1 Study of thick samples (1. $5 \mathrm{~mm})$}

Different $\mathrm{Al}$ contents $: 0.03 \% ; 0.5 \% ; 1 \%$; and $2 \% \mathrm{Al}$ were investigated on $17 \% \mathrm{Cr}$ stabilized stainless steels $(0.3 \% \mathrm{Zr}$ and $0.47 \% \mathrm{Nb})$. The oxidation kinetics are shown in Figure 1.

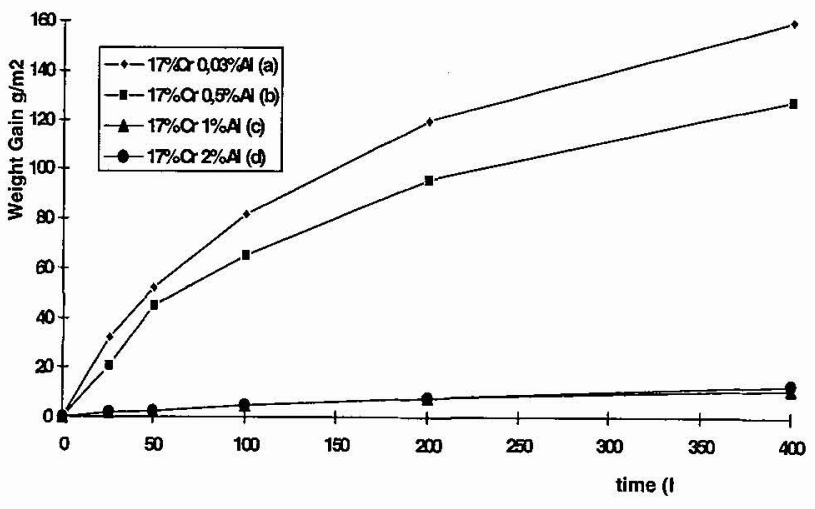

Figure 1 : Oxidation kinetics of $17 \% \mathrm{Cr}$ alloys with various $\mathrm{Al}$ contents. Study on metal coupon $(1.5 \mathrm{~mm})$ at $1000^{\circ} \mathrm{C}$.
From Fig. 1, we can see that $\mathrm{Al}$ additions exert a beneficial effect on oxidation behaviour. At this temperature, a continuous chromia scale is formed on alloy (a) without Al. The chemical composition is confirmed using EPMA (Electron Probe Micro-Analysis) pictures, shown in Figure 2. The oxidation resistance is poor compared to an alumina scale. Thus this chromia-forming alloy leads to a high weight gain.

The alloys containing $1 \% \mathrm{Al}$ (c) or more (d) show very low oxidation rates. This result is related to the formation of a continuous alumina scale. This is confirmed looking at the EPMA pictures given in Fig. 2. A thin external layer of $\mathrm{Cr}_{2} \mathrm{O}_{3}$ was also observed.

The alloy containing $0.5 \% \mathrm{Al}$ (b) exhibits intermediate behaviour close to that of the chromia-forming alloy. The microprobe $\mathrm{X}$ ray maps in Fig. 2 show strong internal oxidation with alumina flakes in the metal near the metal/oxide interface. Beyond this particular shape, the chromia continuous oxide can be seen. In this case, $0.5 \% \mathrm{Al}$ is not enough to form a continuous, protective alumina scale.
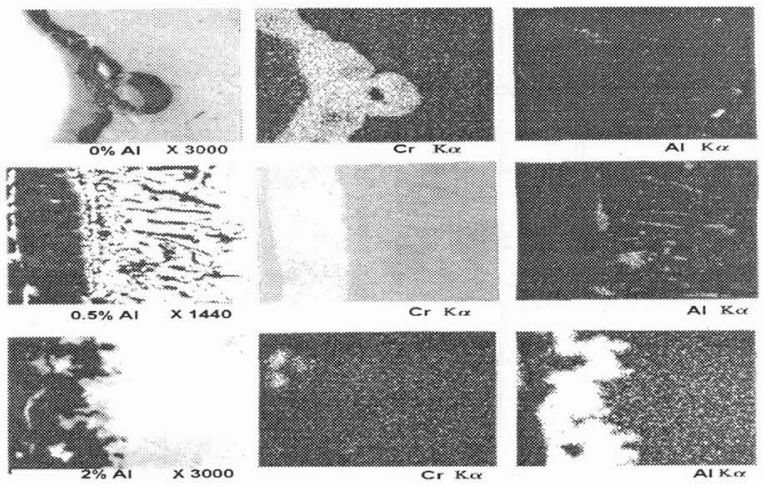

Figure 2 : EPMA study of $17 \% \mathrm{Cr}$ alloys $(1.5 \mathrm{~mm})$ with various Al Contents, after 25 hours at $1000^{\circ} \mathrm{C}$. 


\section{1.2 Influence of thickness of the metal sheet :}

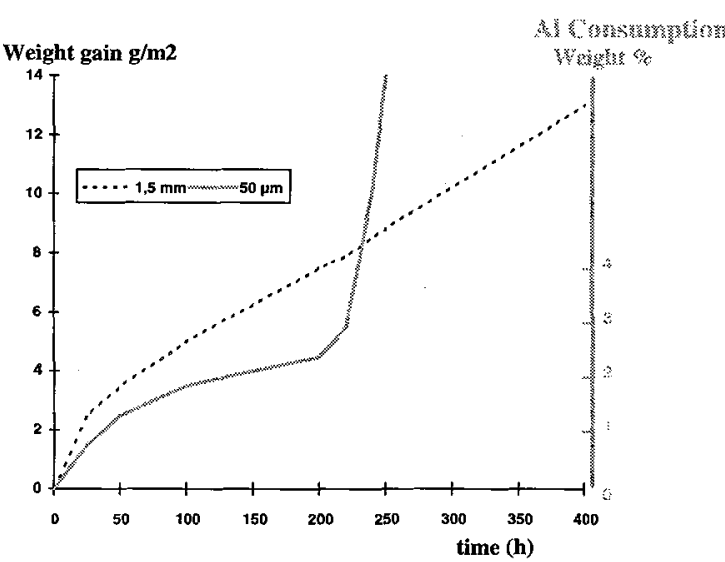

Figure 3 : Influence of thickness on oxidation kinetics at $1000^{\circ} \mathrm{C}$ of $17 \% \mathrm{Cr} 2 \% \mathrm{Al}$ (d). Al consumption is given for the metal foil.
The oxidation kinetics of thick metal coupons $(1.5 \mathrm{~mm})$ and thin foils $(50 \mu \mathrm{m})$ are compared in Figure 3. Two different types of behaviour are observed as a function of time:

- At short times (below $200 \mathrm{~h}$ ), a lower oxidation rate is measured on the thin metallic substrate. There is still an aluminium reservoir in the substrate which provides $\mathrm{Al}$ for $\mathrm{Al}_{2} \mathrm{O}_{3}$ formation.

- At longer times (above $200 \mathrm{~h}$ ), oxide breakaway and immediate large mass gain is seen on the thin foil. The left scale of Fig. 3, shows the $\mathrm{Al}$ consumption measured by EPMA on the foils. A $200 \mathrm{~h}$ time corresponds to the consumption of the whole amount of Al. On the other hand, the thick metal coupon possesses an endless reservoir of aluminium which allows the growth of the $\mathrm{Al}_{2} \mathrm{O}_{3}$ layer.

Lower oxidation kinetics observed on thin foils for shorter times can be explained by two hypotheses. The first one is related to a modification of oxide growth. The decrease of Al content which is effective for the thin foil induces a predominant inward anion diffusion and can slow down the oxidation kinetic. An other explanation can be attributed to a detrimental effect of grain growth during oxidation. As this phenomenon is more limited on the metal foil because the $50 \mu \mathrm{m}$ thickness prevents the grain growth, we can expect better behaviour from the thin foil.

\section{1. 3 Influence of prior surface treatments :}

The lifetime of thin foils depends largely on the $\mathrm{Al}$ reservoir. Thus, the oxidation rate must be as low as possible in order to limit the $\mathrm{Al}$ content. Therefore, and in order to achieve a protective alumina scale directly, without forming a less protective chromia layer first, the influence of prior surface treatments was studied. These treatments were carried out under low oxygen pressure in order to avoid $\mathrm{Cr}, \mathrm{Si}$ and $\mathrm{Mn}$ oxidation. Experiments were carried out on alloy (d) under $\mathrm{H}_{2}: 4 \mathrm{~h}-900^{\circ} \mathrm{C}$ with different $\mathrm{P}_{\mathrm{H}_{2} \mathrm{O}}: 3$ and 15 ppm vol. Figure 4 shows Glow Discharge Optical Emission Spectroscopy of the samples preoxidized at different $\mathrm{P}_{\mathrm{H}_{2} \mathrm{O}}$. A low $\mathrm{P}_{\mathrm{H}_{2} \mathrm{O}}$ treatment leads to a thin oxide film ( $<10 \mathrm{~nm}$ ) which contains mainly $\mathrm{Zr}$ and Al. $\mathrm{Zr}$, similarly to $\mathrm{Al}$, has a strong affinity for oxygen. A higher $\mathrm{P}_{\mathrm{H} 2 \mathrm{O}}$ treatment gives a thicker oxide film (>50 nm) which contains aluminium as a major component. Zirconium contamination is less visible because of the dilution. These oxide films do not contain any chromium, silicon or manganese.
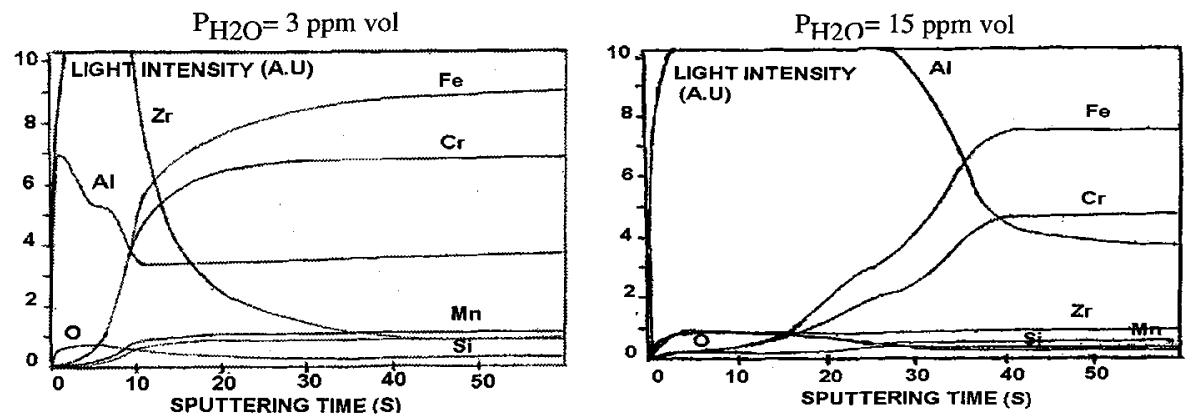

Figure 4 : GDOES of $17 \% \mathrm{Cr} 2 \% \mathrm{Al}$ stabilized alloy (d) preoxidized in hydrogen with different $\mathrm{P}_{\mathrm{H}_{2} \mathrm{O}}$.

The thermogravimetric study is shown in Figure 5. Oxidation experiments were performed at $1100^{\circ} \mathrm{C}$ and reveal a short lifetime for the foils due to low $\mathrm{Al}$ content. 


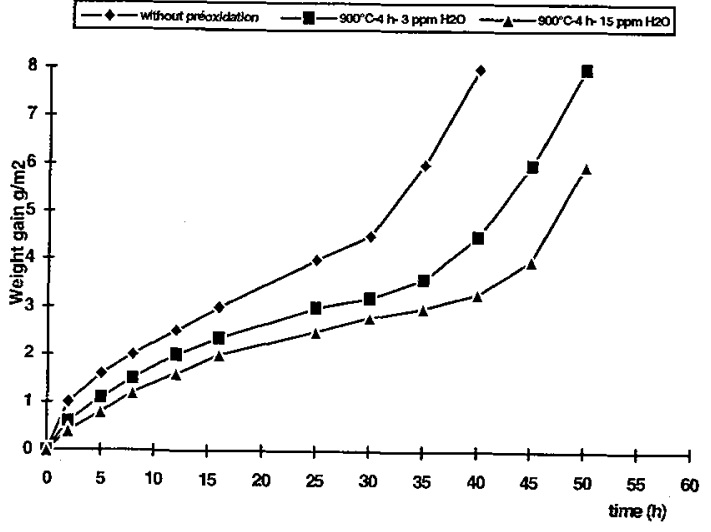

Figure 5 : Oxidation kinetics at $1100^{\circ} \mathrm{C}$ on $17 \% \mathrm{Cr} 2 \% \mathrm{Al}$ stabilized alloy (d). Influence of preoxidation treatment with different $\mathrm{P}_{\mathrm{H}_{2} \mathrm{O}}$.
However, the beneficial effect of the treatment is sensitive. Breakaway oxidation occurs after :

$-25 \mathrm{~h}$. without pre-treatment

- 35 h. with pre-treatment at $\mathrm{P}_{\mathrm{H}_{2} \mathrm{O}}=3 \mathrm{ppm}$ vol.

- $45 \mathrm{~h}$. with pre-treatment at $\mathrm{P}_{\mathrm{H}_{2} \mathrm{O}}=15 \mathrm{ppm}$ vol.

The most beneficial effect is recorded on the thicker alumina scale developed prior to oxidation. Thus, the low Al content of the alloy constitutes the main drawback with respect to oxidation resistance. So preoxidation treatment improves the lifetime of the alumina scale, but not sufficiently to enhance oxidation resistance very much.

\section{2 Influence of chromium content}

The influence of $\mathrm{Cr}$ content was studied in $2 \% \mathrm{Al}$ stabilized stainless steels $(0.3 \% \mathrm{Zr}$ and $0.47 \% \mathrm{Nb})$. Different chromium contents were added : $6 \% \mathrm{Cr}(\mathrm{e}) ; 13 \% \mathrm{Cr}$ (f); $17 \% \mathrm{Cr}$ (d); and $20 \% \mathrm{Cr}(\mathrm{g})$.

\section{2. 1 Study of thick samples $(1.5 \mathrm{~mm})$}

Oxidation kinetics are shown in Figure 6. Two types of behaviour can be distinguished according to the chromium content. Lower $\mathrm{Cr}$ alloy gives fast oxidation kinetics, showing that $6 \% \mathrm{Cr}$ is not enough to help the formation of stable and continuous alumina scale. It was found that $13 \% \mathrm{Cr}$ has to be added to favour alumina scale formation and provide high oxidation resistance. As Fig. 6 shows, the beneficial effect of $\mathrm{Cr}$ content above $13 \%$ is not clear for alumina-forming alloys.

\section{2. 2 Influence of grain growth :}

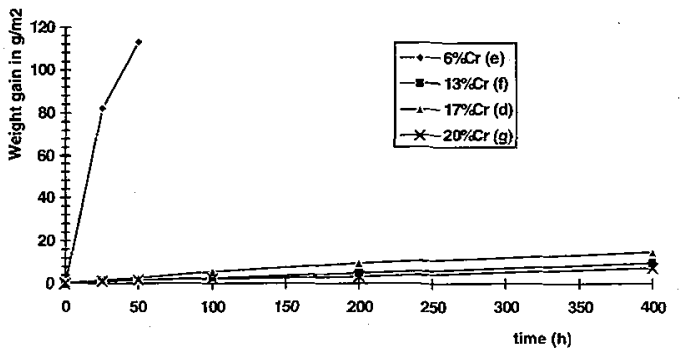

Figure 6 : Influence of $\mathrm{Cr}$ content on oxidation kinetics for $2 \% \mathrm{Al}$ stabilized alloys at $1000^{\circ} \mathrm{C}$.

Although the chemical composition acts as a major parameter favouring oxidation resistance, an elevated running temperature also modifies the metallurgical properties of the substrate, and this in turn induces changes in the external oxide layer.

At elevated temperatures grain growth occurs even on stabilized stainless steel due to $\mathrm{Fe}_{2} \mathrm{Nb}$ dissolution. Thus, surface modifications can occur through grain growth. Figure 7 gives the weight gain, after an oxidation test at $1050^{\circ} \mathrm{C} 24$ hours, of $2 \%$ Al stabilized stainless steels with 13 and $20 \%$ $\mathrm{Cr}$ :

- the beneficial effect of chromium content is not clearly demonstrated after standard annealing in inert atmosphere at $1000^{\circ} \mathrm{C}$ - for a few minutes. However, after a long annealing treatment at $1050^{\circ} \mathrm{C}$ for 24 hours in an inert atmosphere, a beneficial effect of large $\mathrm{Cr}$ additions on subsequent oxidation is observed.

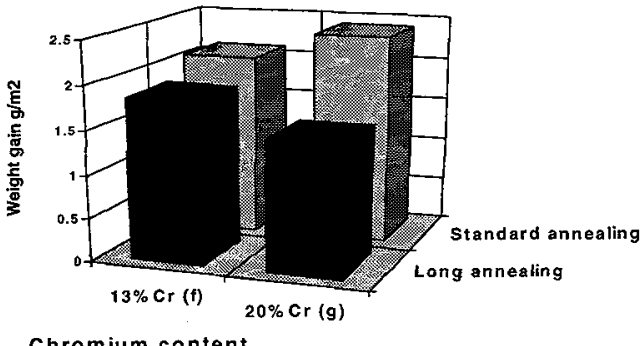

Chromium content

Figure 7 : Influence of prior grain growth treatment on weight gain $\left(1050^{\circ} \mathrm{C}-24\right.$ hours) of $2 \% \mathrm{Al}$ alloys. 
Figures 8 and 9, respectively, show the grain growth kinetics and the simultaneous weight gain at $1050{ }^{\circ} \mathrm{C}$ of $1.5 \mathrm{~mm}$ thick $13 \% \mathrm{Cr} 2 \% \mathrm{Al}$ and $20 \% \mathrm{Cr} 2 \% \mathrm{Al}$ alloys after a standard annealing treatment. These figures help to explain the effect of grain growth on oxidation behaviour. Thus, faster grain growth is observed on the lower $\mathrm{Cr}$ alloy, as shown in Fig. 8, and the grain size reaches a steady state value after only 4 hours at $1050^{\circ} \mathrm{C}$. On the other hand, for the higher $\mathrm{Cr}$ alloy, slow and continuous grain growth is observed up to 24 hours. The oxidation kinetics shown in Fig. 9 show parabolic laws. However, we can see that the parabolic constant is higher for the $20 \% \mathrm{Cr}$ content alloy. This means a less protective oxide as compared to the lower chromium content alloy.

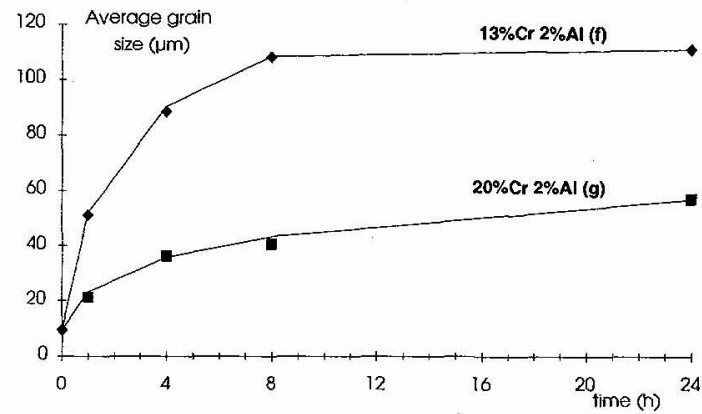

Figure 8: Grain growth kinetics on thick metal coupons on $13 \% \mathrm{Cr} 2 \% \mathrm{Al} \mathrm{(f)}$ and $20 \% \mathrm{Cr} 2 \% \mathrm{Al}(\mathrm{g})$ stabilized alloys at $1050^{\circ} \mathrm{C}$.

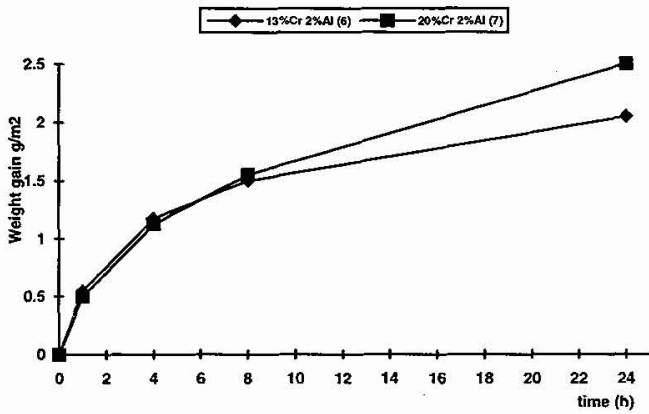

Figure 9 : Oxidation kinetics on thick metal coupons on $13 \% \mathrm{Cr} 2 \% \mathrm{Al}(\mathrm{f})$ and $20 \% \mathrm{Cr} 2 \% \mathrm{Al}(\mathrm{g})$ stabilized alloys at $1050^{\circ} \mathrm{C}$.

In fact, the oxide scale is destabilized by the grain motion inducing impurity segregation at the metal/oxide interface, modifying the manner of oxide growth and decreasing the oxide pegs. Moreover, grain boundaries constitute short diffusion circuits. Therefore and according to these results, slow grain growth during oxidation does not seem to be beneficial for oxidation behaviour.

\section{3 Influence of active element additions :}

\section{3. 1 Yttrium or Mischmetal (Ce, La)}

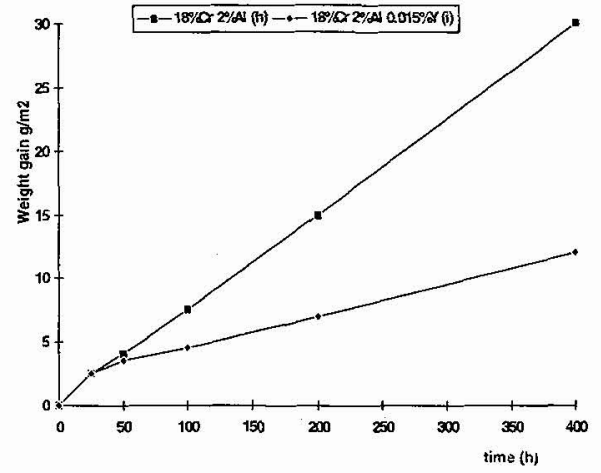

Figure 10 : Influence of $\mathrm{Y}$ addition on $18 \% \mathrm{Cr} 2 \% \mathrm{Al}$ thick coupons at $1000^{\circ} \mathrm{C}$.
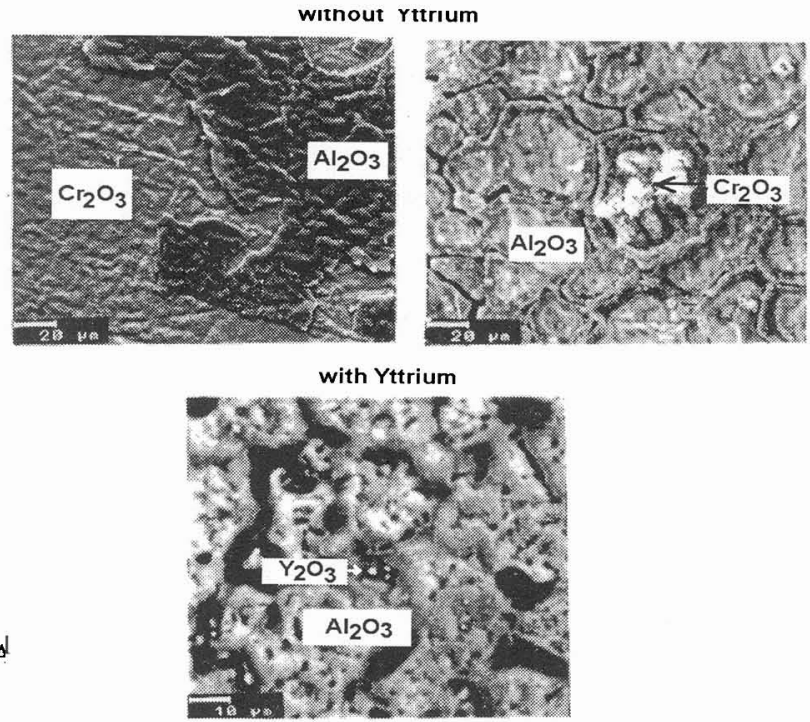

Figure 11 : SEM micrographs on surface alumina scale formed on $\mathrm{Fe} 18 \% \mathrm{Cr} 2 \% \mathrm{Al}$ alloys (i) with and (h) without yttrium.

The influence of active elements such as yttrium was studied in $\mathrm{Fe} 18 \% \mathrm{Cr} 2 \% \mathrm{Al}$ alloys without stabilizers in order to determine separately the effects of conventional active elements (group IIIB) and the 
effects of $\mathrm{Zr}$ used as a stabilizer (group IVB) on oxidation behaviour. Thus, as shown in Figure 10, yttrium addition has a clear beneficial effect on oxidation resistance. Study by SEM, in figure 11, reveals that the major effect is a drastic improvement in scale adhesion. The absence of active elements leads to scale spallation even without thermal cycling. The presence of ytrrium on the outer surface of the oxide scale is also observed. Mischmetal addition, which is a combination of a few active elements (cerium, lanthanum, etc...), improved the oxidation resistance of $\mathrm{FeCrAl}$ alloys in a similar way to yttrium.

\section{3. 2 Zirconium and niobium stabilizers}

Stabilizers are added to stainless steels for full stabilization of the ferritic structure and to improve hot workability. In fact, these elements have a strong chemical affinity for carbon and nitrogen, which are residual impurities in stainless steels. The stabilizers tie up carbon and nitrogen to form stable compounds : $\mathrm{ZrC}, \mathrm{ZrN}$ and $\mathrm{Nb}_{\mathrm{x}} \mathrm{C}_{\mathrm{y}} \mathrm{N}_{\mathrm{z}}$. Moreover, $\mathrm{Nb}$ is added for creep resistance. This element combines with iron to form intermetallic compounds such as $\mathrm{Fe}_{2} \mathrm{Nb}$. They are localised at the grain boundaries, and limit grain growth. $\mathrm{Nb}$ has a low oxygen affinity compared to $\mathrm{Al}$ and does not participate at relatively low content $(<0$. $6 \%$ ) to oxide scale formation. It is very different for $\mathrm{Zr}$, which has a strong affinity for oxygen. Free zirconium (not combined with carbon and nitrogen) can participate in oxide layer formation and can be compared to an active element.

Free zirconium $(\Delta \mathrm{Zr})$ content is estimated by the following relation : $\Delta \mathrm{Zr}=\% \mathrm{Zr}-7(\% \mathrm{C}+\% \mathrm{~N})$

Where $\% \mathrm{Zr}$ is the total zirconium content, \% $\mathrm{C}$ and $\% \mathrm{~N}$ are respectively carbon and nitrogen contents in the alloy.

Figure 12 shows oxidation kinetics on $\mathrm{Fe} 17$ $18 \% \mathrm{Cr} 2 \% \mathrm{Al}$ alloys :

- with no further addition (i)

- with $\mathrm{Zr}$ and $\mathrm{Nb}$ additions (d)

- with $\mathrm{Zr}, \mathrm{Nb}$ and $\mathrm{Y}$ additions (g).

Regarding Fig. 12, the following remarks can be made :

- the addition of stabilizers markedly improved oxidation behaviour

- stabilizers and yttrium additions together give the lower weight gain.

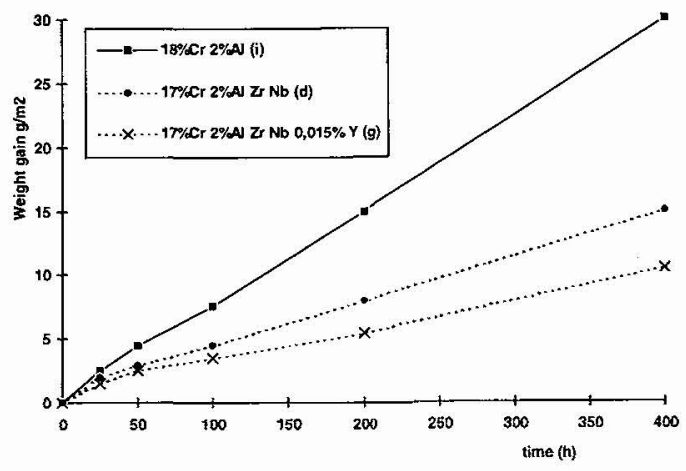

Figure 12 : Influence of stabilizers ( $\mathrm{Zr}$ and $\mathrm{Nb}$ ) and yttrium additions on $17 \% \mathrm{Cr} 2 \% \mathrm{Al}$ thick coupons at $1000^{\circ} \mathrm{C}$.

The different forms of zirconium in the oxide scale are shown in Figure 13. This element appears as nodules or in solution in the alumina scale. The nodules can emerge at the surface. The presence of zirconium generally promotes internal oxidation.

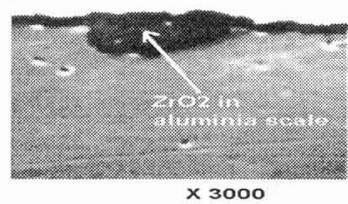

X $\mathbf{3 0 0 0}$

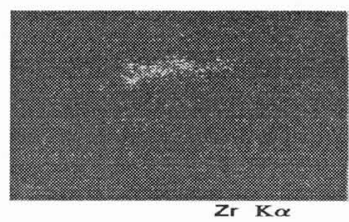

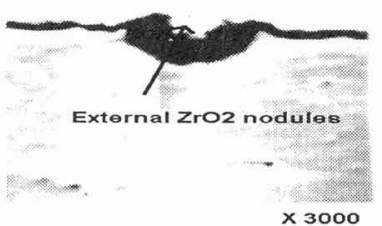

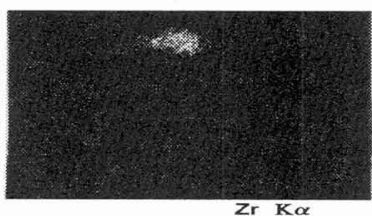

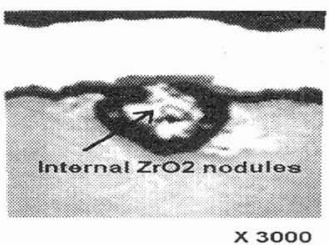

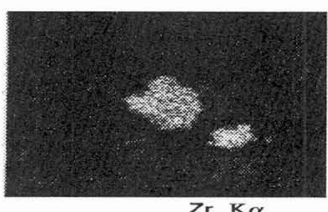

Figure 13 : different forms of $\mathrm{Zr}$ in the oxide (EPMA Study). 
Two $\mathrm{Fe} 17 \% \mathrm{Cr} 2 \% \mathrm{Al}$ alloys ( $\mathrm{d}$ and $\mathrm{k}$ ) with different $\Delta \mathrm{Zr}$ are compared in Figure 14. It is clear that $\mathrm{Zr}$ addition has a beneficial effect on oxidation behaviour.

High levels of free zirconium induce a noticeable degradation of the properties. In fact, zirconium oxide nodules increase with $\mathrm{Zr}$ content. Thus zirconia is less protective than alumina and can, in large quantities, affect the oxidation resistance. Hence $\mathrm{Zr}$ additions must be controlled.

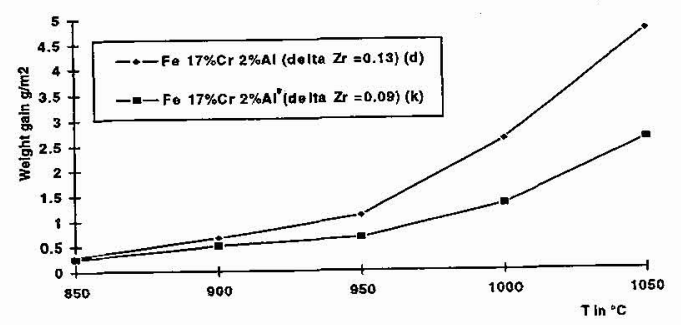

Figure 14 : Influence of temperature on oxidation behaviour after 24 hours. Influence of $\Delta \mathrm{Zr}$.

\section{4 Influence of minor additions or impurities :}

\section{4. 1 Influence of silicon}

Silica formation occurs at the end of the life of metallic foils when the Al reservoir is not sufficient to provide oxide formation. Silica formation occurs at the inner part of the oxide (metal/oxide interface). A particular pyramidal morphology is attributed to silica as shown in Figure 15.
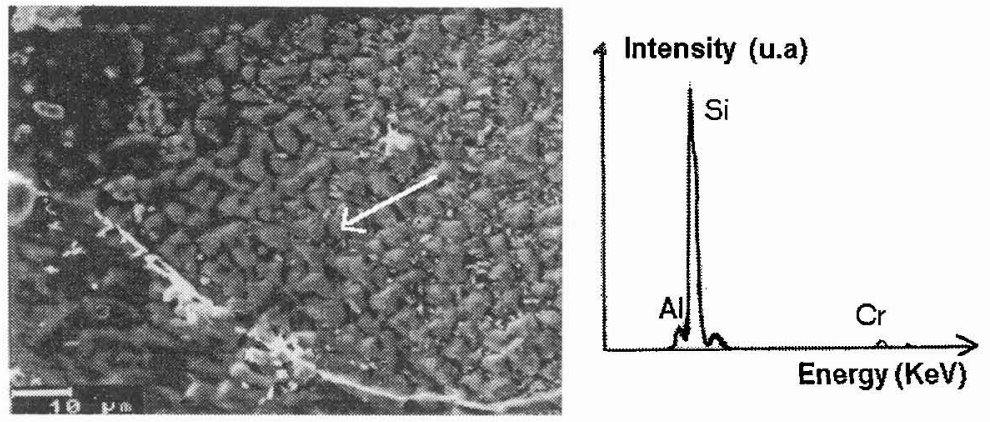

Figure 15 : SEM study of metal/oxide interface after pickling the metal substrate with a chemical reagent.

\section{4. 2 Influence of manganese}

Manganese is present as an impurity in the metal and its content is below $1 \%$. This element has a high chemical affinity for oxygen and participates in oxide scale formation. As can be seen in Figure 16, Mn is generally associated with $\mathrm{Cr}$ and is localised in the outer part of the alumina scale. Manganese oxides have a porous morphology. Manganese is also detected in defect zones, such as oxide cracks.
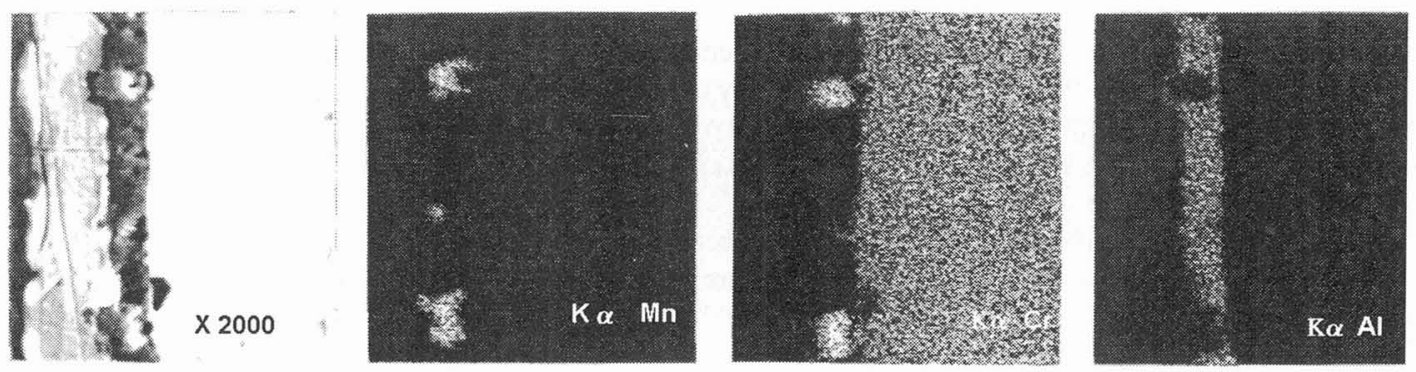

Figure 16 : EPMA study on Fe20\%Cr 5\%Al alloys oxidised at $1100^{\circ} \mathrm{C}$. 


\section{4. 3 Influence of sulphur}

Stabilized zirconium Fe $18 \% \mathrm{Cr} 4 \% \mathrm{Al}$ alloys with different sulphur contents : $20 \mathrm{ppm}(\mathrm{m})$ and $50 \mathrm{ppm}(\mathrm{l})$ are oxidised at $1100^{\circ} \mathrm{C}$. The results are shown in Figure 17.

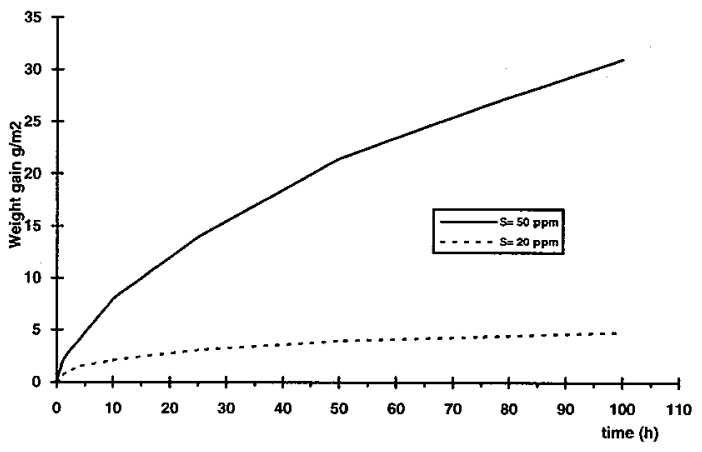

Figure 17 : Influence of sulphur contents : $S=20 \mathrm{ppm}$ (m) and $50 \mathrm{ppm}$ (l) on oxidation kinetics of $18 \% \mathrm{Cr} 4$ $\% \mathrm{Al} \mathrm{Zr}$ thick metal coupons at $1100^{\circ} \mathrm{C}$.

\section{DISCUSSION}

\section{1 Critical aluminium and chromium contents}

The first steps of alumina scale formation are identified in the following way $(1,2,3)$ :

$\mathrm{Cr}$ has high chemical activity in the metal. This allows formation of a chromia-rich layer which constitutes a transition scale. The formation of a rather protective layer induces a decrease in oxygen diffusion to the metal and a simultaneous decrease of oxygen pressure at the metal/oxide interface. The oxygen partial pressure at the metal/oxide interface is given by the dissociative pressure of the external chromium oxide. The slow-down of oxygen diffusion prevents internal aluminium oxidation and enhanced formation of a continuous alumina layer.

Thus, $\mathrm{Al}$ diffusion to the surface below the oxide is enhanced. In this way, an alumina healing layer can be formed immediately beneath the chromia rich transient scale. This highly protective oxide induces a strong decrease of the oxygen pressure at metal/oxide interface up to the oxygen dissociation pressure of alumina. The Gibbs energy formation of oxides is given at $1000^{\circ} \mathrm{C}$ :

$*-522 \mathrm{~kJ} / \mathrm{mol} \mathrm{O} 2$ for $\mathrm{Cr} 2 \mathrm{O} 3$

* $-585 \mathrm{~kJ} / \mathrm{mol} \mathrm{O} 2$ for $\mathrm{MnO}$

* $-677 \mathrm{~kJ} / \mathrm{mol} \mathrm{O} 2$ for $\mathrm{SiO} 2$

* $-844 \mathrm{~kJ} / \mathrm{mol} \mathrm{O} 2$ for Al2O3.

Thus, among the most oxidizable elements in the alloy, only alumina can be formed and gives rise to oxide growth. In this process, $\mathrm{Cr}$ and $\mathrm{Al}$ levels play an important role in alumina scale formation. According to our results, an $\mathrm{Al}$ content of $1 \%$ is sufficient to provide a continuous $\mathrm{Al} 2 \mathrm{O} 3$ formation. A lower content $(0.5 \% \mathrm{Al})$ gives large internal alumina flakes without forming a healing continuous scale. This phenomenon is due to the lack of $\mathrm{Al}$ at the surface when transient scale formation occurs.

A low $\mathrm{Cr}$ content alloy $(6 \%)$ gives an insufficiently chromia-rich transient scale for a marked decrease in oxygen pressure at the oxide/metal interface. The fast oxygen diffusion through the scale does not allow $\mathrm{Al}$ enrichment at the interface and the continuous alumina scale layer cannot be formed. A value of $13 \% \mathrm{Cr}$ is required to obtain protective alumina layers.

However, another parameter has to be taken into account in oxidizing thin metallic foils. The breakaway oxidation observed with low $\mathrm{Al}$ content $(2 \%)$ at short oxidation times is caused by the lack of $\mathrm{Al}$ supply from the metal substrate to form an alumina scale. Al content in the foils must reach a value of $5 \%$ to provide acceptable oxidation resistance (3). Otherwise, different treatments prior to oxidation were studied and exert an influence on bulk properties like grain growth or on metal surfaces. The decrease in grain size generally favours diffusion in the metal and in this way the formation of a stable healing scale is enhanced (4). Grain growth of the substrate during oxidation is detrimental. In this case, the oxide layer is 
destabilized, both mechanically and chemically. When grain growth cannot be avoided, it is shown that fast growth is preferable. Thus, grain growth occurs in a thin layer which is better able to accommodate strains and chemical modifications at the metal/oxide interface.

Prior treatment in a reducing atmosphere and with low water vapour content drastically decreases oxygen pressure at the metal/oxide interface. Thus a protective alumina scale can be formed directly without the establishment of any chromia transient scale. This treatment tends to decrease the minimum $\mathrm{Cr}$ and $\mathrm{Al}$ contents for alumina layer formation. Oxidation resistance is enhanced, but it is not sufficient, and this does not allow $\mathrm{Al}$ and $\mathrm{Cr}$ contents to be drastically limited.

\section{2 Influence of active elements}

Several theories have been proposed to explain the influence of active elements on oxide adhesion $(5,6)$ as :

- vacancy sinks in the oxide, which eliminate the formation of voids

- development of oxide pegs by internal oxidation from the scale to the substrate

- formation of an oxide compound, which accommodates differential dilatation strains between the oxide and the substrate generated by cyclic oxidation

- improvement of scale plasticity or chemical bonding

- decrease in growth stresses by modification of the scale growth mechanism

- tying up of sulphur at the metal/oxide interface and formation of a refractory compound.

Sulphur is known to decrease the surface energy of the substrate and thus segregates easily to the metal/oxide interface. Sulphur is detrimental to the adherence of the scale because it forms low melting compounds with metal, or reduces chemical bonding between oxide and metal (7).

The influence of active elements reaches maximum efficiency at low concentrations (a few tens of ppm). Catastrophic effects on hot workability $(8,9)$ and properties $(9)$ are caused by high active element levels. $\mathrm{Zr}$ is not only used as a stabilizer but also as an active element. However $\mathrm{Zr}$ is less effective in tying up sulphur than group IIIB elements. It has a beneficial effect on oxide adherence. Similarly to common active elements ( $\mathrm{Y}, \mathrm{Ce}$, and $\mathrm{La}$ ), the free zirconium content must be lower than $1000 \mathrm{ppm}$ to provide high oxidation properties. In fact, $\mathrm{Zr}$ (group IVB element) at higher levels acts as an oxygen getter and forms oxide nodules in the scale. These defects are less protective than alumina and conduce to a degradation of oxidation resistance.

\section{3 Influence of minor additions and impurities}

Influence of niobium :

$\mathrm{Nb}$ is generally added as a stabilizer for its ability to form intermetallic compounds such as $\mathrm{Fe}_{2} \mathrm{Nb}$. Thus, the chemical oxygen affinity for $\mathrm{Nb}$ is lower than for Al. At levels of about $0.5 \%, \mathrm{Nb}$ has never been detected in alumina scale. However, we must mention that various oxide compounds can be formed, such as $\mathrm{NbO}, \mathrm{NbO}_{2}$ and $\mathrm{Nb}_{2} \mathrm{O}_{5}$. These oxides are not protective or stable at high temperatures $(10)$.

Influence of manganese :

This element is commonly present in industrial alloys. $\mathrm{Mn}$ is generally located in the outer part of the oxide scale and in oxide cracks which are fast diffusion pathways, as shown in Fig. 15. This phenomenon is linked to the fast diffusibility ( $>\mathrm{Cr}$ and $\mathrm{Fe}$ ) of this element at high temperatures. $\mathrm{Mn}$ is associated with $\mathrm{Cr}$ to forms spinelle oxide $\mathrm{MnCr}_{2} \mathrm{O}_{4}$ in the alumina scale (11). This type of oxide is less protective than $\mathrm{Cr}_{2} \mathrm{O}_{3}$ and is also known to be detrimental in alumina-forming alloys (12).

Influence of silicon :

When $\mathrm{Al}$ is totally exhausted from the matrix, silicon is oxidised in silica $\left(\mathrm{SiO}_{2}\right)$ at the metal/oxide interface. This compound has a peculiar morphology and exhibits a pyramidal shape on FeCrAl alloys (see Fig. 14). Si is known to have a beneficial effect on $\mathrm{FeCr}$ alloys (13). Diffusion of detrimental species (Fe, $\mathrm{Mn}$ ) is limited by $\mathrm{SiO}_{2}$ barrier in the inner part of the oxide. Thus $\mathrm{Si}$ is found to retard breakaway oxidation after complete $\mathrm{Al}$ depletion.

Influence of sulphur :

Sulphur has a detrimental effect, as mentioned above in the section on the influence of active elements.

\section{CONCLUSIONS}

It is shown that $\mathrm{Al}$ addition is very effective for high temperature oxidation resistance of $\mathrm{FeCr}$ alloys. $1 \% \mathrm{Al}$ leads to a continuous protective $\mathrm{Al}_{2} \mathrm{O}_{3}$ oxide on $\mathrm{FeCr}$ alloy that contains more than $13 \%$ of $\mathrm{Cr}$. 
However, this aluminium content is not enough for high temperature resistance of thin foils and $5 \% \mathrm{Al}$ is necessary, since the substrate plays the role of an aluminium reserve capable of being oxidised. Impurity elements such as sulphur are detrimental and give rise to spalling of the oxide layer. Therefore, active elements such as $\mathrm{Y}, \mathrm{Ce}, \mathrm{La}, \mathrm{Zr}$ are necessary to tie up sulphur and increase the life of the alloys.

\section{Acknowledgement}

Part of this research was conducted under European CECA project 7210/MA/313.

\section{References}

(1) G. C. Wood, F. H. Stott, Mat. Sci. and Technol. , 1987, vol 3 pp 519-530

(2) R. G. Miner, V. Nagarajan, Ox. of Met. 1981, vol. 16, n³/4, pp 313-325

(3) T. Kawasaki, K. Ishii, Proceedings of internationnal conference on Stainless Steels, 1991 Chiba, Japan.

(4) S. N. Basu, G. C. Yurek, Ox. of Met. 1991, vol. 36, N³/4, pp 281-315

(5) D. P. Moon, Mat. Sci. and Technol. , 1989, vol 5 pp 754-764

(6) D. R. Sigler, Ox. of Met. 1989, vol. 32, n'5/6, pp 337-355

(7) J. G. Smeggil, A. J. Shuskus, N. S. Bornstein and M. A. de Crescente, in The Role of Active Elements in the Oxidation Behaviour of High Temperature Metals and Alloys, E. Lang, Elsevier Applied Science, 1988, pp 271-285.

(8) J. H. Davidson, in The Role of Active Elements in the Oxidation Behaviour of High Temperature Metals and Alloys, E. Lang, Elsevier Applied Science, 1988, pp 353-365.

(9) K. Ohmura, M. Yamanaka, M. Fukaya, H. Abo, and S. Funaki, in Heat Resistant Materials, Proceedings of the First International Conference, Fontana, Wisconsin, USA, September 1991, pp 505513.

(10) P. Kofstad, in High Temperature Oxidation of Metals, John Wiley and Sons, New York, 1966.

(11) F. H. Stott, Mat Sci. dnd Technol. , 1989, vol. 5, pp 734-740

(12) N. Hiramatsu, K. Miyakusa and Y. Uematsu, in Heat Resistant Materials, Proceedings of the First International Conference, Fontana, Wisconsin, USA, September 1991, pp 1227-1234

(13) J. Robertson, M. I. Manning, Mat. Sci. and Technol. , 1989, vol. 5, pp 741-753 